States Formerly Prohibiting Miscegenation

Iowa........ Omitted in 1851.

Kansas...... Omitted 1857. See Laws, c. 49 (1857).

Maine....... Repealed 1883. See Laws, p. 16 (1883).

Massachusetts Repealed 1840. See Acts, c. 5 (1843).

Michigan... Prior interracial marriages legalized 1883. See Comp. Laws, $\S 12,695$ (1929).

New Mexico.. Repealed 1886. See Laws, p. 90 (1886).

Ohio....... Repealed 1887. See Laws, p. 34 (1887).

Rhode Island. Repealed 1881. See Acts, Jan. Sess., p. 108 (1881).

Washington. . Repealed 1867. See Laws, pp. 47-48 (1867).

\title{
VENUE IN ANTITRUST CASES: APPLICABILITY OF THE NEW DISCRETIONARY TRANSFER PROVISION
}

INCLUDED in the recently revised Judicial Code is a new provision, Section 1404(a), permitting transfer of venue in civil actions to accommodate the convenience of parties and witnesses. ${ }^{1}$ The legislative history of the section, despite the use of the broad phrase "any civil action," leaves unsettled the question of whether antitrust actions are included.

The Sherman Act, ${ }^{2}$ although it made no special venue provision for Government antitrust actions, expressly permitted private treble damage suits to be brought wherever the defendant "resides or is found." " In Section 12 of the Clayton Act, Congress enlarged the plaintiff's choice of forums to include those in which the defendant "transacts business." While the enlarged choice was made available to all plaintiffs, including large corporations and the Government, ${ }^{5}$ apparently the main purpose of the provision

1. Pub. L. No. 773, 80th Cong., 2d Sess., $\$ 1404$ (a) (June 25, 1948).

2. 26 StAт. 209 (1890), as amended, 15 U.S.C. $\$ \$ 1-7$ (1946).

3. Prior to enactment of the Clayton Act (see note 4 infra), $\$ 7$ of the Sherman Act provided: "Any person who shall be injured in his business or property by any other person or corporation by reason of anything forbidden or declared to be unlawful by this act, may sue therefor in any circuit court of the United States in the district in which the defendant resides or is found, without respect to the amount in controversy, and shall recover three fold the damages by him sustained, and the costs of suit, including a reasonable attorney's fee."

4. "That any suit, action, or proceeding under the antitrust laws against a corporation may be brought not only in the judicial district whereof it is an inhabitant, but also in any district wherein it may be found or transacts business; and all process in sttch cases may be served in the district of which it is an inhabitant, or wherever it may be found." 38 STAT. 736 (1914), 15 U.S.C. \$22 (1946).

By including the phrase "or transacts business," $\$ 12$ expands $\$ 4$ of the Act, 38 STAT. 736 (1914), 15 U.S.C. $\$ 15$ (1946), which specifically provides that treble damage suits may be brought where the defendant "resides or is found or has an agent." It also expands $\$ 7$ of the Sherman Act, which dealt wholly with treble damage actions brought by private plaintiffs. See Eastman Kodak Co. v. Southern Photo Material Co., 273 U.S. 359 (1927).

5. Although there had been little difficulty in the past in bringing actions in the 
was to prevent the escape of wealthy corporate defendants to jurisdictions where an impecunious plaintiff could not afford to sue. ${ }^{\circ}$ Underlying the provision was the emotional aura which surrounded, and still surrounds, the picture of an abused David slaying the corporate Goliath with a legal slingshot.

An unfortunate corollary of permitting an impecunious plaintiff to sue even where the venue is inconvenient to the defendant is that any plaintiff, impecunious or not, can deliberately choose such a forum in order to make defense of the suit unnecessarily expensive, ${ }^{8}$ usually in an effort to force a settlement. Thus, while this risk may be justified where the plaintiff cannot afford to sue elsewhere, an inherent defect in the statute has been that wealthy corporate plaintiffs or the Government ${ }^{9}$ would benefit unduly from the opportunity to shop around for the most advantageous forum. A dual problem exists of providing for antitrust venue in such a way as to give the

home jurisdiction of the defendants, the Attorney General requested that venue be broadened to permit greater freedom in bringing suits. There vas some fear that this might lead to abuse, but this was allayed by pointing to the fact that the same policies would be followed as under the Sherman Act, and that on the whole antitrust actions under that Act had been brought in the defendants' home districts. 51 Co:sc. REc. 9414-7 (1914). Attempted amendments to prevent the opportunity of abuse vere attaclied successiully on the same grounds. Id. at $9466-7$.

6. The purpose of the expansion of venue in $\$ 12$ was to protect the "injured person" from the often insuperable obstacle of resorting to distant forums. United States v. Scophony Corp., 333 U.S. 795, S08 (1948). See United States v. National City Lines, 334 U.S. 573, 580, 581 (1948) ; Eastman Kodak Co. v. Southern Photo MIaterials Co., 273 U.S. 359, 373, 374 (1927). The Government is no such "injured nerson." U.S. v. Cooper Corp., 312 U.S. 600 (1940) (Government cannot sue for treble damages). 1940).

7. See Haninton and Til, Antrtrust in Action 82-S5 (TNEC Monograph 16,

8. The very size of many antitrust suits makes transportation of dccuments, witnesses and counsel a costly operation. See Comment, 49 YALE L. J. 284, 290 (1939). The Government has used the threat of the expense of defending antitrust suits with telling effect. "Indeed, it has been the unvarying experience of the Antitrust Division that a pending prosecution has the same effect in brealing up restraints of trade as a conviction-that even the acquittal makes the defendants draw a breath of rulief and resolve never to undergo such an expensive hazard again." Arwold, The Bormenectss of Business 210 (1st ed. 1940).

9. While the Government may once have been deserving of the same special assistance as the indigent private plaintiff, the Antitrust Division seems to have outgrown such status. For the fiscal year ending June 30,1949, the appropriation for the Antitrust Division was $\$ 3,411,700$, Pub. L. No. 597, E0th Cong., 2d Sess. (June 3, 1949), as compared with $\$ 580,060$ for the fiscal year ending June 30, 1939, 52 Srst. 260 (193\$). The Government was spending roughly $\$ 100,000$ to $\$ 150,000$ on its biggest antitrust suits even before the war. Handler, Federal Antrtrest Actions 92 (TNEC Mronograph 38, 1941). In 1947 the Antitrust Division counted 175 lawyers, 21 experts, 97 stenographers, 41 typists, and 10 messengers on its staff. 93 Coxis. Res. 9682 (1947). In addition to its regular personnel the Antitrust Division draws heavily on the Federal Bureau of Investigation for assistance in investigations and in interviewing witnesses. The Division can reach any forum with relative ease from one of its nine regional offices. Sre U:iTED States Governarent Manual 206 (1948). 
indigent plaintiff special assistance and at the same time close the door to possible abuse.

In criminal antitrust proceedings the broad choice of venue has been abused in at least one instance. ${ }^{10}$ In United States $v$. Socony Vacumm Oil Co. ${ }^{11}$ prosecution of an alleged conspiracy to fix prices of oil products was brought in Madison, Wisconsin-hundreds of miles from where prices allegedly were set, where the conspiracy allegedly was executed, and where the witnesses lived.12 Largely because of this case Rule 21(b) of the Federal Rules of Criminal Procedure was adopted in 1946 providing for transfer "in the interest of justice" to any other forum in which the offense had been committed. ${ }^{13}$

But while Rule 21(b) effectively checks abuse of venue in criminal antitrust actions, provisions to prevent the possibility of abuse in civil antitrust actions have lagged behind. ${ }^{14}$ Although the Supreme Court in 1947 recog-

10. Another alleged instance was American Tobacco Co. v. United States, 147 F. 20 93 (6th Cir. 1944), where venue in the tobacco country enabled the selection of juror's from among those injured by the practices complained of by the Government. The trint judge's refusal to sustain challenges for cause of at least four of the jurors was even appealed, though unsuccessfully. Id. at 118. The Supreme Court in granting certiorari refused to review the question. 324 U.S. 836 (1944).

It is possible, however, that venue was selected because the dockets in other available jurisdictions were overcrowded.

11. 310 U.S. 165 (1939).

12. See Comment, 49 YALE I. J. 284, 290 (1939). For a sample of the protest against the venue in the Madison Oil case, see Bus. Week, Oct. 19, 1937, p. 15, col. 2.

13. "Rule 21 (b). Offense Committed in Two or More Districts or Divisions, Tho court upon motion of the defendant shall transfer the proceeding as to him to another district or division, if it appears from the indictment or information or from a bill of particulars that the offense was committed in more than one district or division and if the court is satisfied that in the interest of justice the proceeding should be transferred to another district or division in which the commission of the offense is charged." Followint 54 STAT. 688 (1940), 18 U.S.C. \$ 687 (1946).

This rule was directed expressly at antitrust cases such as the Madison Oil casc. Youngquist, Institute Proceedings, Federal Rules of Criminal Procedure 169, 170 (N.Y.U. ed. 1946). Professor Dession, one of the advisors on the Criminal Rules, saw a two-fold advantage in application of the rule to antitrust cases: it would prevent the Government's shopping around for an "unduly favorable locality and judge," and would permit charges of unfair venue by defendants "to be litigated in court rather than cxclusively in the press." Dession, Neze Rules of Criminal Procedure: II, 56 YaLE L. J. 197, 224, 225 (1947). And see Judge Medalie in Institute Proccedings, Federal Rules of Crininal Procedure 274-5 (N.Y.U. ed. 1946). The head of the Antitrust Division admitted the need for the rule in large scale conspiracy cases. Berge, The Proposed Fcderal Rules of Criminal Procedure, 42 Micr. L. REv. 353, 379 (1943).

14. Defendants in the past have tried to change venue by attacking jurisdiction in terms of the venue provision itself, questioning whether they are "found" or "transict business" within the jurisdiction rather than contending that the forum is inconvenient. E.g., Winkler-Koch Engineering Co. v. Universal Oil Products Co., 70 F. Supp. 77 (S.D. N.Y. 1946) (plaintiff, apparently with main offices in Chicago, sued defendant, also with main offices in Chicago, in New York) ; Sure-Fit Products Co. v. Fry Products, 23 F. Supp. 610 (S.D. N.Y. 1938) (Michigan corporation with main office in Michigan 
nized the doctrine of forum non conzeniens, thus permitting courts to dismiss civil suits brought in an inconvenient forum, ${ }^{15}$ the attempts of antitrust defendants to obtain dismissal under the doctrine have generally been unsuccessful, even where made in good faith. Motions for dismissal have been overruled on the merits, ${ }^{16}$ or because courts have felt that the doctrine did not apply to antitrust venue, ${ }^{17}$ or on both of these grounds. ${ }^{15}$

A final decision that forum non conzeniens does not apply to antitrust venue was made by the Supreme Court in United Stales $ฆ$. Nalional Cily Lines. ${ }^{19}$ The case involved nine corporations charged with conspiracy to restrain competition in motorbus transportation and in the purchase of essential supplies. The action had been dismissed on a showing that the Southern District of California was an inconvenient forum. $: 3$ For the same reason, the criminal antitrust action against the same defendants had already been transferred to the Northern District of Illinois under Rule 21(b). 21 The Supreme Court reversed on the ground that the venue section of the Clayton Act made choice of forum a statutory "right" which could not be limited by the judicial doctrine of formm non conceniens. The Court went further to point out important considerations militating against such a dismissal: it would not only initially delay the suit, but might also result in a "merry-goround of litigation"'22 by leading to dismissal in other courts.

Since this decision, however, the new Judicial Code has come into effect. ${ }^{23}$

but with a salesman in N.Y. sued by a Pennsylvania plaintiff in New York). Oceasionally, before the adoption of formm non conzeniens, there had been an attempt to involse some discretionary power to relieve an apparently oppressive selection of venue, but the courts until recently denied having any such power. "The facts that it may be more convenient to parties and will avoid protracted litigation in this court if this case is tried in Ot:lahoma are circumstances which do not make the jurisdiction of this court dependent upon the exercise of a discretion." Momand v. Paramount Pictures Distributing Co., 19 F. Supp. 102, 104 (D. Mass. 1937) ; United States v. Standard Oil Co. of N. I., 152 Fed. 290 (C.C.E.D. Mo. 1907), aff'd, 221 U.S. 1 (1911) (some seventy defendants, only one of which was resident of the district, most being from the New York ares).

15. Gulf Oil Corp. v. Gilbert, 330 U.S. 501 (1947); Koster v. Lumbermens Mfutual Casualty Co., 330 U.S. 518 (1947). The background and nature of the doetrine has been ably discussed in Barrett, The Doctrine of Forum Non Conventiens, 35 CaLIr. L. Rer. 380 (1947) ; Braucher, The Incontenient Federal Fortm, 60 Hurs. L. Fev. 908 (1947); Comment, 56 Y ALE L. J. 1234 (1947); Note, 34 VA. L. Rev. $\$ 11$ (1948).

16. Fifth \& Walnut v. Loew's Inc., 76 F. Supp. 64 (S.D.N.Y. 1948); United States v. Standard Oil Co. of Calif., 7 F.R.D. 338 (S.D. Calif. 1947).

17. Tivoli Realty v. Interstate Circuit, 167 F. $2 d 155$ (5th Cir. 1948), ccrl. dericd, 334 U.S. 837 (1948).

18. Ferguson v. Ford Motor Co., 77 F. Supp. 425 (S.D.N.Y. 1948).

19. 334 U.S. 573 (1948).

20. United States v. National City Lines, 7 F.R.D. 456 (S.D. Calif. 1947).

21. United States v. National City Lines, 7 F.R.D. 393 (S.D. Calif. 1947).

22. 334 U.S. 573, 591-2 (1948).

23. The National City Lines case was decided on June 7, 1948. The new Judicial Code, see note 1 supra, was signed by the President on June 25, 194\$, and came into effect on Sept. 1, 1948. 
Section 1404(a), in providing for the transfer of civil actions for the convenience of parties and witnesses, ${ }^{24}$ codifies forum non conveniens, but with the important difference that it provides for transfer instead of dismissal. ${ }^{26}$ Under this provision the Southern California District Court has now transferred the National City Lines case to the Illinois District on the same grounds on which it had dismissed it prior to the Supreme Court's reversal. ${ }^{20}$

The decision in this latest phase of the National City Lines case, that Section 1404(a) applies to venue in antitrust cases, resolves a question left unanswered by the legislative background. To the extent that the sectioncodifies forum non conveniens it may be argued that antitrust cases are excluded, for they were so excluded from the application of that doctrine itself. Yet the reviser's notes cite a case under the Federal Employer's Liability Act, which was also excluded from forum non conveniens, "27 "as an example of the need" for enactment of the section, ${ }^{28}$ so that FELA cases would appear clearly subject to its operation. ${ }^{29}$ Any inference as to antitrust cases, how-

24. "For the convenience of parties and witnesses, in the interest of justice, a district court may transfer any civil action to any other district or division where it might havo been brought." Pub. L. No. 773, 80th Cong., 2d Sess., \$1404(a) (June 25, 1948).

25. Reviser's Notes, 28 U.S.C. Cong. Serv. 1853 (1948).

26. United States v. National City Lines, 17 U.S.L. WeEK 2167 (S.D. Calif. Oct. 12, 1948). Motion for leave to file petition for werit of certiorari assigned for hearing bcfore the Suprente Court. 17 U.S.L. WEEK 3188 (U.S. Dec, 21, 1948).

27. Baltimore \& Ohio R.R. v. Kepner, 314 U.S. 44, 54 (1941). ("A privilege of venue, granted by the legislative body which created this right of action, cannot be frustrated for reasons of convenience or expense. If it is deemed unjust, the remedy is legislative. . . ."). See Gulf Oil Corp. v. Gilbert, 330 U.S. 501, 505 (1947); Miles v. Illinols Central R. R., 315 U.S. 698 (1942). See Braucher, The Inconvenicnt Federal Forim, 60 Harv. L. Rev. 908, 914 (1947) ; Comment, 56 Yale L.J. 1234, 1241 (1947).

28. "Subsection (a) was drafted in accordance with the dactrine of formm non conveniens, permitting transfer to a more convenient forum, even though the venue is proper. As an example of the need of such a provision, see Baltimore \& Ohio R. Co. v. Kepner, 1941, 62 S. Ct. 6, 314 U.S. 44, 86 L.Ed. 28, which was prosecuted under the Federal Employer's Liability Act in New York, although the accident occurred and the employec resided in Ohio. The new subsection requires the court to determine that the transfer is necessary for convenience of the parties and witnesses, and further, that it is in the interest of justice to do so." 28 U.S.C. Cong. SERv. 1853 (1948). See Galston, An IIItroduction to the New Federal Judicial Code, 8 F.R.D. 201, 206 (1948).

29. Several cases have already considered the applicability of $\$ 1404$ (a) to FELA actions. Holding that it does apply: Kilpatrick v. Texas \& Pacific Ry., S.D. N.Y., Nov. 22, 1948 ; Nunn v. Chicago, M., St. P. \& P.R.R., 17 U.S.L. WeEk 2222 (S.D.N.Y. Nov. 9, 1948) ; Hayes v. Chicago, R.I. \& P.R.R., 79 F. Supp. 821 (D. Minn. 1948) ; Collett v. Louisville \& Nashville R.R., 17 U.S.L. WEek 2223 (E.D. Ill. Oct. 18, 1948). Contra: Pascarella v. New York Central, 81 F. Supp. 95 (E.D. N.Y. 1948). A motion for leave to file petition for writ of mandamus or certiorari was made to the Supreme Court in the Kilpatrick case, supra, on Nov. 23, 1948, and was assigned for hearing. 17 U.S.L. WEEk 3188 (U.S. Dec. 21, 1948).

In the Pascarella case, sipra. Judge Rayfiel argues that $\$ 1404$ (a) applies only to those civil actions enumerated in Chapter 87 of the Judicial Code under which the section falls. However, $\$ 33$ of the new code forbids drawing any such inference as to legislative construction. Furthermore $\$ 1406$, also a new provision which provides for transfer when 
ever, is not conclusive. ${ }^{30}$

The essential difference between Section 1401(a) and formm non conveniens, that transfer rather than dismissal is provided, strongly supports the conclusion that antitrust actions were meant to be, and should be, included. ${ }^{31}$ This difference counters the objections expressed by the Supreme Court in the National City Lines case when it was considering forum non

the venue is improper, clearly applies to all civil actions even though it is located in Chapter 87. Thus the position of $\$ 1404$ (a) in Chapter 87 does not in itself show a limited application. See Hayes v. Chicago, R.I. \& P.R.R., 79 F. Supp. 821, \&25 (D. Minn. 194\$).

Judge Rayfiel also argues that $\S 1404$ is no more than consolidation of $\$ 119$ [24 STAT. 425 (1887), as amended, 28 U.S.C. $\$ 119$ (1940)] (providing for transfer of civil actions upon stipulation of parties) and $\$ 163$ [39 STAT. $\$ 51$ (1916), 28 U.S.C. $\$ 163$ (1940)] (permitting transfer from one division to another within a district) of the Judicial Code, that these sections do not apply to FELA actions, and therefore that $\$ 1404$ does not so apply. In any event, $\S 163$ is embodied in $\$ 1404(\mathrm{~b})$, and $\$ 119$ in $\$ 1404(\mathrm{c}) ; \S 1404(\mathrm{a})$ is a new provision independent of these sections.

It might be argued that Congress' failure to enact the Jennings Bill, H.R. 1699, which was designed to change FELA venue, shows that Congress did not intend to affest FELA venue when it enacted $\$ 1404(\mathrm{a})$. The bill, however, was passed by the House, 93 Co:ic. REc. 9193 (1947), and was referred to the Senate Committee on the Judiciary just ten days behind the revision of the Judicial Code, which included $\$ 1404$ (a) complete with the reviser's notes signifying the contemplated application to cases like the Kchncr case, note 27 supra. Id. at S422, 9249. Sce Hayes v. Chicago, R.I. S P.R.R, 79 F. Supp. \$21, \$25 (D. Minn. 1948). Furthermore, discussion of the Jennings Bill before a subcommittee induded recognition of the fact that $\$ 1404$ (a) would permit transfer of FELA actions, and this does not appear to have been questioned. Hearings before Subcommillec of the Commiltce on the Judiciary on S. 1567 and H.R. 1659, S0th Cong., 2d Sess. 111 (1948). This leads to the very fair inference that Congress thought that $\$ 1404$ (a) adequately achieved the end sought by the Jennings Bill.

30. There was no specific need for the reviser's notes to consider abuses in antitrust venue, since no case had yet been decided by the Supreme Court involving the question of discretionary relief from an inconvenient antitrust venue. The reviser's notes were ordered printed on April 25, 1947. 93 CoNG. Rec. 4114 (1947), whereas the Supreme Court did not decide the National City Lines case, until June 7, 1948.

In any event, the words "any civil action" would seem to be all inclusive. When exceptions were intended in the new Judicial Code they seem to have been specifically spelled out. E.g., $\$ 2680$ (listing exceptions to c. 171). See 3 MLone's Fenaral Prnetree 2141 n. 107 (2d ed. 1948) : "Any' action in \$1404(a) includes suits subject to special venue statutes, as suits for patent infringement and suits under the Federal Employer's Liability Act, as well as actions subject to the general venue statute"

31. It might be argued that Congress was not thoroughly apprised of the impending changes in $\$ 1404$ (a) from the fact that the new Judicial Code was enacted by way of the consent calendar without debate on the floor. But an interested Congressman could casily have spotted the change by reading the reviser's notes and records of the committee hearings. On Mar. 7, 1947, Prof. Mroore testified before the Subcommittce of the House Committee on the Judiciary: "Venue provisions have not been altered by the revision. Two changes of importance have, however, been made. Improper venue is no longer grounds for dismissal of action in the federal courts. Instead the district court is to transfer the case to the proper venue. See section 1406. And section 1404 introduces an element of convenience which gives the court the power to transfer a case for the convenience of parties and witnesses to another district." 28 U.S.C. Cong. SERV. 1969 (1948). 
conveniens: there is no longer the chance of a chain of dismissals, ${ }^{32}$ and the possibility of delay is greatly diminished. ${ }^{33}$.

The Supreme Court in the National City Lines case raised another potential difficulty by speaking of the broad choice of venue provided in the Clayton Act as a "right" which could not be limited by the exercise of judicial discretion. ${ }^{34}$ Since the provisions of Section 1404(a) also contemplate judicial discretion, the Supreme Court might reiterate this principle as limiting the application of the Section's provisions. But here discretion, being authorized by act of Congress, is not a wholly judicial development as in the case of forum non conveniens. And while reference to the choice of venue as a "right" may suggest that the choice can be modified only by specific amendment of the Clayton Act, courts can easily reach the opposite decision by labelling the "right" as procedural; ${ }^{35}$ other courts, moreover, have obviated the problem by construing choice of venue as a "privilege." 30 Yet in terms of practical effect, the label is immaterial: since Section 1404(a)

32. Under the new provision the court to which an action is transferred is, by the law of the case, the convenient forum. Only new evidence could change the finality of such a transfer.

33. The time which the Court feared would be consumed in review of a dismissal (334 U.S. 573, 590 (1948)) should be avoided under \$1404(a), for transfer of an action does not seem to be a final disposition which can be appealed. See FED. R. Crv. P. 54(a) (b). Only by a decision of the Supreme Court that transfer under $\$ 1404(a)$ is a final judgment can the delay to which the Court objected in the case of dismissal (a final disposition) become a reality. The Court has agreed to hear arguments on the question in the form of a motion for leave to file a petition for ceritorari in the National City Lincs casc. 17 U.S.L. WEEK 3188 (U.S. 1948). If the motion is granted, not only would delay in antitrust actions result from transfer under $\$ 1404(\mathrm{a})$, but similar delays would restult in all civil actions of every description. There is some indication, however, that the Court does not consider transfer to another forum a reviewable final order. Sec United States v. National City Lines, 334 U.S. 573, 594 and note 43 (1948) (expressing doubt that transfer of a criminal action under Rule 21 (b) could be appealed).

Of course where the decision on the motion to transfer has been extremely unfair to either plaintiff or defendant there is a possibility of delay if a petition for prerogative writ of mandamus is entertained by the Supreme Court. Pub. L. No. 773, 80th Cong., 2d Sess, $\S 1651$ (a) (June 25, 1948). But considering the purpose of the writ, that of correcting glaring and extreme inequities, any delay stemming from its issuance scems justifiable.

Another possible source of delay would be transfer to a district with a crowded calcndar. It is probable, however, that in actions by a private litigant this is an element to te considered by the trial judge in determining "interest of justice." As for the Government's actions, no delay need result; Congress has provided that these actions may, upon request of the Attorney General, "be given precedence over others and in every way expedited. . . ." 32 Stat. 823 (1903), as amended, 15 U.S.C. $\$ 28$ (1940).

34. 334 U.S. 573, 587, 597 (1948).

35. "No one obtains any vested right in venue. It is granted by legislative cnactment and can be withdrawn by the same power. The right is procedural and not substantive." Hayes v. Chicago, R.I. \& P.R.R., 79 F. Supp. 821, 824 (D. Minn. 1948) (holding that $\$ 1404$ (a) limits the right under FELA).

36. See Tivoli Realty v. Interstate Circuit, 167 F. 2d 155, 158 (5th Cir, 1948); Baltimore \& Ohio R.R. v. Kepner, 314 U.S. 44, 54 (1941). 。 
operates only when venue is proper, ${ }^{37}$ venue under Section 12 of the Clayton Act must be established before Section 1401(a) comes into operation. Thus no amendment is necessary. ${ }^{35}$

It would be a curious anomaly to have a provision for the transfer of criminal antitrust actions and then to exclude civil antitrust actions from a similar provision. The purposes of transfer are fundamentally the same in both cases. ${ }^{39}$ Furthermore, when both a civil and criminal action are brought by the Government, the defendant is effectively prevented from obtaining a transfer of the criminal action unless the civil action can similarly be transferred. By moving to transfer the criminal action, he invites the burden of defending two suits in different parts of the country at the same time. And while the Government might pursue only one action at a time, it could still choose the civil action which cannot be transferred from the inconvenient forum; moreover, the Government would have its choice of the more favorable judge of the two available.

The application of Section 140 (a) to antitrust actions provides a check against possible abuse of venue without disturbing the purpose behind the broad venue provisions of the Clayton Act. That courts will not misuse the power to transfer is assured by standards and precedents already established in cases involving forum non conceniens. ${ }^{40}$ The requirement that transfer

37. Where venue is improper, $\$ 1406$ applies. See Prof. Mloore's statement before the Subcommittee of the House Judiciary Committee quoted in note 31 supra. Sce Hayes v. Chicago, R.I. \& P.R.R., 79 F. Supp. 821, 824 (D. MIinn. 1948).

38. Forthn non conveniens has also been held inapplicable to FELA and antitrust actions on the ground that they involve "special venue statutes." Gulf Oil Corp. v. Gilbert, 330 U.S. 501 (1947); Tivoli Realty v. Interstate Circuit, 167 F. $2 d 155$ (5th Cir. 1948). Fifth \& Walnut v. Loew's, Inc, 76 F. Supp. 64, 69 (S.D.N.Y. 1948). And see Mr. Justice Jackson, concurring in United States v. National City Lines, 334 U.S. 573, 597 (1948). But $\$ 1404$ (a) seems applicable to special as well as general venue statutes, the implied requirement being only that the venue is proper. MCORE, of. cit. stipra note 30 , at $2141 \mathrm{n} .107$.

39. The guiding principle in both Rule 21 (b) and $\$ 1404$ (a) is "the interest of justice" The difference between whether an antitrust action is criminal or civil seems insufficient to result in material variation between the factors determining the "interest of justice" as to venue in either type of case.

40. In judging whether a forum is convenient "important considerations are the relative ease of access to sources of proof; availability of compulsory process for attendance of unwilling, and the cost of obtaining attendance of willing, witnesses; possibility of view of premises, if view would be appropriate to the action; and all other practical problems that make trial of a case easy, expeditious and inexpensive. There may also be questions as to the enforceability of a judgment if one is obtained. The court will weigh relative advantages and obstacles to fair trial. It is often said that the plaintifi may not, by choice of an inconvenient forum, 'vex,' 'harass,' or 'oppress' the defendant by inficting uron him espense or trouble not necessary to his own right to pursue his remedy. But unless the balance is strongly in favor of the defendant, the plaintiff's choice of forum should rarely be disturbed" Gulf Oil Corp. v. Gilbert, 330 U.S. 501, 50 S (1947). See Koster v. Lumbermen's Mutual Casualty Co., 330 U.S. 518, 526 (1947) ; Barrett, The Doctrine of Formsn Non Conveniesis, 35 Calrf. L. Rev. 380,416 (1947); Comment, 56 Yale L. J. 1234, 1247 (1947).

Lower courts in considering applications for dismissal under formm non conzcuticns 